\title{
Sprawozdanie ze zjazdu księży profesorów i wykładowców historii Kościoła. Wigry, 11-13.04.2012 roku
}

W dniach od 11 do 13.04.2012 roku w pokamedulskim zespole klasztornym na Wigrach odbyło się spotkanie profesorów i wykładowców historii Kościoła. Od czterdziestu ośmiu lat, zawsze w tygodniu po Wielkanocy, spotykają się ci, którzy z pasją zajmują się badaniem historii Kościoła, jak i edukacją. Tym razem okazją do spotkania i tematem przewodnim konferencji naukowej stała się dwudziesta rocznica ogłoszenia bulli Totus Tuus Poloniae Populus papieża Jana Pawła II z 25.03.1992 roku wprowadzającej nowy podział administracyjny Kościoła katolickiego w Polsce. W wygłoszonych referatach zostały przypomniane zmiany $\mathrm{w}$ administracji kościelnej na ziemiach polskich od chwili ustanowienia pierwszych biskupstw i arcybiskupstwa w Gnieźnie aż do ostatnich zmian w 2004 roku.

Spotkanie rozpoczęło się 11.04, we środę, od wspólnej kolacji. Gospodarzem tegorocznego spotkania była diecezja ełcka, stąd uczestnictwo w kolacji biskupa ełckiego Jerzego Mazura, który następnego dnia z rana przewodniczył Eucharystii w wigierskim kościele pw. Niepokalanego Poczęcia Najświętszej Maryi Panny i wygłosił okolicznościową homilię.

Konferencja naukowa rozpoczęła się od wystąpienia ks. dr. hab. Włodzimierza Bielaka z Katolickiego Uniwersytetu Lubelskiego, który wygłosił referat pt. Organizacja kościelna w średniowieczu - normy $i$ praktyka. Ks. prof. dr hab. Anzelm Weiss podzielił się swą wiedzą dotyczącą bezpośredniego podporządkowania ordynariatów biskupich papieżowi, stąd temat jego wystąpienia: Biskupstwa bezpośrednio podporzadkowane Stolicy Apostolskiej. Trzecim referatem w porannej sesji było wystąpienie ks. prof. dr hab. Józefa Krętosza z Uniwersytetu Śląskiego w Katowicach pt. Wptyw etatyzmu na organizację Kościoła katolickiego na ziemiach polskich zaboru austriackiego.

Krótka przerwa na kawę stała się okazją nie tylko do wymiany doświadczeń, wiedzy czy uzupełnieniem wygłoszonych referatów, ale 
także sposobnością do zapoznania się z nowymi wydawnictwami dotyczącymi historii Kościoła. W Wigrach pojawiło się stoisko wydawnictwa Biały Kruk, które promowało nową, czterotomową serię dotyczącą historii Kościoła w Polsce pt. Kościót na straży polskiej wolności. Pierwszy tom, autorstwa prof. Krzysztofa Ożoga, pt. Korona i Krzyż. Czas Piastów i Jagiellonów, dotyczy czasu kształtowania się państwowości polskiej w zgodzie z Ewangelia i misją Kościoła. Coroczne spotkanie historyków, już od wielu lat, jest okazją do zdobycia przez nich najnowszych wydawnictw naukowych. Księża profesorowie - autorzy naukowych publikacji dzielą się swym dorobkiem naukowym, przywożąc ze sobą książki, często niedostępne w księgarniach, wydawane w nielicznych nakładach.

W drugiej części sesji zabrał głos ks. dr hab. Wojciech Guzewicz, wykładowca historii Kościoła w ełckim seminarium, organizator tegorocznego zjazdu. Wygłosił wykład nt. Zagadnienie organizacji kościelnej w Drugiej Rzeczpospolitej. Po nim referat dotyczący Reorganizacji diecezji pruskich w 1821 roku wygłosił ks. prof. dr hab. Andrzej Kopiczko z Uniwersytetu Warmińsko-Mazurskiego.

Przedpołudniowe obrady zakończyły się dyskusją, w której padło wiele cennych uzupełnień czy zapytań. Autorzy referatów starali się odpowiedzieć na wszystkie postawione pytania.

Po posiłku w porze południowej organizatorzy zaproponowali objazd i zwiedzanie okolicznych miejscowości. Wielu uczestników konferencji było bowiem na Wigrach po raz pierwszy. Trasa wiodła przez Sejny, Studzieniczną, Augustów i Suwałki. Zachwycały nie tylko śliczne krajobrazy, piękno jezior czy lasów Puszczy Augustowskiej, ale także cisza i panujący spokój.

W Sejnach uczestnicy konferencji zwiedzili bazylikę pw. Nawiedzenia Najświętszej Maryi Panny, byłą katedrę diecezji sejneńskiej wpisaną w kompleks zabudowań podominikańskich. Świątynia znana jest z siedemnastowiecznej figury, słynącej cudami, Matki Bożej Sejneńskiej, koronowanej koronami papieskimi w 1975 roku. W Studzienicznej, proboszcz tamtejszej parafii, przywitał uczestników zjazdu w zabytkowym drewnianym kościele słynącym ze zdobień z poroży dzikich zwierząt. Zaprosił następnie do Sanktuarium Matki Bożej Studzieniczańskiej, gdzie modlono się przed obrazem Matki Bożej, do której w 1999 roku pielgrzymował także papież Jan Paweł II. Wizytę tę upamiętnia pomnik Ojca Świętego autorstwa Czesława Dźwigaja. W Augustowie i Suwałkach księża zwiedzili kościoły: Matki Bożej Częstochowskiej, pobudowany pierwotnie, jako cerkiew prawosławna, oraz kościół św. Aleksandra z I połowy XIX wieku, będący konkatedrą. 
Pierwszy dzień obrad, pełen nowych wiadomości i wrażeń, zakończyła kolacja i koleżeńskie spotkanie księży profesorów.

Następnego dnia mszy świętej przewodniczył i kazanie wygłosił bp Jan Marian Kopiec, nowo mianowany ordynariusz diecezji gliwickiej. Po zakończonej mszy świętej była możliwość zwiedzenia krypt pod świątynią, w których pogrzebani zostali mnisi - kameduli, jak i pomieszczeń w zabudowaniach klasztornych, w których odpoczywał papież Jan Paweł II podczas swego pobytu na Wigrach w 1999 roku.

Drugi dzień obrad był już znacznie krótszy. Wykłady zaplanowano tylko w sesji przedpołudniowej, gdyż wielu księży czekała długa droga powrotna. W pierwszej części swój referat wygłosił ks. dr Adam Szot, dyrektor Archiwum Archidiecezjalnego w Białymstoku i wykładowca historii w tamtejszym seminarium. Tematem wystąpienia były Zmiany organizacyjne Kościoła katolickiego obrzadku tacińskiego $w$ Imperium Rosyjskim $w$ latach 1772-1848. Autorem kolejnego referatu był ks. prof. dr hab. Stanisław Wilk SDB, rektor Katolickiego Uniwersytetu Lubelskiego Jana Pawła II. Z powodu jego nieobecności przeczytał go - w imieniu rektora - o. dr Arkadiusz Smagacz OCD, adiunkt Katedry Historii Zakonów na KUL.

Po krótkiej przerwie na kawę o najnowszych zmianach w administracji kościelnej na ziemiach polskich mówili: ks. dr. Robert Masalski i ks. dr Tomasz Moskal. Ich referaty dotyczyły tematu: Bulla „Episcoporum Poloniae ceoetus"-geneza i konsekwencje. Bulla wydana przez papieża Pawła VI w 1972 roku normalizowała stosunki prawne między PRL a Watykanem i ustalała nowy podział administracyjny na Ziemiach Odzyskanych.

Po wygłoszeniu referatów był jeszcze czas na krótką dyskusję i podanie spraw organizacyjnych. Miejscem następnego zjazdu księży profesorów i wykładowców historii Kościoła wyznaczono Pelplin. Przyszłoroczne obrady mają dotyczyć kwestii misji w Kościele powszechnym i zaangażowania Kościoła polskiego na polu działalności misyjnej. Zjazd na Wigrach zakończył się obiadem, podczas którego podano wigierską specjalność - sielawę.

W pamięci wszystkich uczestników zjazdu pozostanie nie tylko zdobyta wiedza, odnowione relacje i przyjaźnie, ale głęboko wpisze się cisza panująca w pokamedulskim klasztorze oraz piękno wigierskich jezior.

Ks. Adam Szot 